\title{
Sumpit (Blowgun) as Traditional Weapons with Dayak High Protection
}

\author{
(Study Documentation of Local Wisdom Weak Traditional Weapons of Kalimantan) \\ Hamid Darmadi \\ IKIP PGRI Pontianak, Pontianak, Indonesia \\ E-mail: hamiddarmadi@gmail.com
}

\begin{abstract}
The Dayak ancestors who live amid lush forests with towering tree trees and inhabited by a variety of wild animals and wild animals, inspire for the Dayak's ancestors to make weapons that not only protect themselves from the ferocity of forest life but also have been able to sustain the existence of their survival. Such living conditions have motivated the Dayak ancestors to make weapons called "blowgun" Blowgun as weapons equipped with blowgun called damak. Damak made of bamboo, stick and the like are tapered and given sharp-sharp so that after the target is left in the victim's body. In its use damak smeared with poison. Poison blowgun smeared on the damak where the ingredients used are very dangerous, a little scratched it can cause death. Poison blowgun can be made from a combination of various sap of a particular tree and can also be made from animals. Along with the development of blowgun, era began to be abandoned by Dayak young people. To avoid the typical weapons of this high-end Dayak blowgun from extinction, need to be socialized especially to the young generation and to Dayak young generation especially in order, not to extinction.
\end{abstract}

Keywords: Typical Dayak High-Pressed Weapons Squack

\section{INTRODUCTION}

The Dayak ancestors who live amid lush forests with towering tree trees and inhabited by a variety of wild animals and wild animals have inspired the forefathers of Dayaks to make weapons that not only protect themselves from the viciousness of forest life but also able to sustain their lives both morally and materially. Based on these conditions and the purpose of the Dayak make a special weapon, one of them is a weapon that is considered quite unique and then better known as. "Blowgun". Blowgun consists of three parts, namely: Stem (pipe blowgun, Damak (children blowgun) and caged blowgun (eyes spears made of iron or rock mounts tied firmly to the end of the blowgun pipe.) Weapons that rely on this blowing force can hit the effective targets from 25 to 30 meters apart either vertically or horizontally (depending on the ability of the blower).

With the weapons of Dayak blowgun can paralyze the enemies and game animals both on the tree like birds and wild animals that live on land from a distance far away. With the ability to target animals and enemies remotely, Dayaks have created high-density self-protection devices feared by invaders. In practice the use of blowgun, if it turns out the first shot does not hit the target, and otherwise wild animals or enemies counterattack from close range that results in damek (damak) cannot be used effectively or did not have time to install damak pipe chopper made of wood beleng with at the end become weapons that are very useful to protect themselves from close range. The existence of cavalier at the end of the pipe blowgun is like a bayonet on the tip of the rifle or spear eye that is ready to be used in case of close attack the enemy.

In order to be more effective in blowgun, especially for the purpose of hunting or against the enemy, Dayaks smear the damak with poison made from plant sap. According to the story of the Dayak elders, the poison on the damak (child blowgun) there is no antidote so that animals or people affected by this weapon even though only scratched will cause death. What is very unique again and hard to think of healthy reasoning, animals that die from weapons blowgun meat is not toxic and safe to eat (Kompas 24 December 204). In addition to the lethal range and toxic blowgun, another advantage of this device is that when used it does not cause sound. This silent element is very important when targeting game animals or enemies are not off guard. Aside from being a hunting and fighting weapon, blowgun is also used for customary or traditional wedding equipment in wedding Dayak. (Kompas, December 24, 2004). 
In line with the changing times and changes in mindsets and natural conditions where Dayaks live, they have an effect on the existence (existence) of blowgun as a distinctive weapon. Blowgun gradually began to be abandoned Dayak young people and it is not impossible in the future weapons that high enough value of this high protracted sooner or later will be extinct. Therefore it is necessary to immediately be preserved so that the traditional equipment that is a typical weapon Dayak is still maintained its existence from time to time. The presence of blowgun that increasingly began to be left encourage writers to choose this issue as a study with the title: "Blowgun As Traditional Weapons Typical Dayak Protected High feared invaders" (Study Documentation of Local Wisdom Weak Traditional Weapons of Kalimantan).

\section{LITERATURE REVIEW}

\section{A. Understanding Blowgun}

The blowgun is one of the weapons often used by the Dayak tribe. In addition to hunting, blowgun became a tool of war. In terms of its use blowgun or sipet has its own advantages because it can be used as a weapon remotely and does not damage the natural because of the natural manufacture. And one of the advantages of blowgun or sipet has a shooting accuracy that can reach 218 yards or about 200 meters. Viewed from the shape of blowgun, blowgun has a round shape and has a length of between 1.5-2 meters, about 2-3 centimeters in diameter. At the end of this blowgun are targeted like a small shell-like diamonds measuring 3-5 centimeters. At the center of the blowgun perforated as a place to enter damek (child blowgun). At the top of the blowgun more precisely on the front of the target is a spear or machete (in the Dayak language). Sangkoh made of stone mountains ago tied with woven uei (rattan).

Types of wood commonly used to make blowgun, in general, are wood looks, ironwood or tabalien, plepek wood, and wooden resak. Not to forget also tamiang ataulamiang, which is a kind of small bamboo, long beruas, hard, and contains poison. Not everyone has the expertise in making blowgun or sipet. On the island of Borneo, there are only a few tribes who have expertise in making blowgun, the Dayak Ot Danum, Punan, Apu Kayan, Bahau, Siang, and Dayak Pasir tribe. In the process of making blowgun or sipet done in two ways, namely the first skill of the hand of the maker. The second way, namely by using power from nature by utilizing the strength of the flow of cascade water made into a kind of rice pounder mill. The selling price of blowgun or sipet has been determined by customary law, ie jipen ije or due taheta halamaung.

According to Dayak beliefs, blowgun should not be used to kill sesame, except to play a role. Blowgun can only be used for everyday purposes, such as hunting. Blowgun is not allowed or abstain from being trampled let alone cut with machetes because if they are violated customary law, which may result in the perpetrators being sued in customary meetings. In colonial times in Borneo in ancient times,
Dutch troops armed with rifles with the latest technology of its time, while Dayak soldiers generally only rely on blowgun. However, the Dutch soldiers were far more afraid of children blowgun than the Dayak soldiers hit by bullets. What makes the colonists tremble is a child of poisonous blowgun. Before leaving for the battlefield, the Dayak soldiers smeared the children's eyes with blowgun with sap of ipuh trees or iren trees. In silence, they act to release the blowgun called the damak.

Without knowing the whereabouts of his opponent, suddenly one by one the Dutch soldiers sprawled, leaving the rest of his surviving comrades running scampered. Even had time to respond with a shot, the impact of hot tin was far out of balance with the fierce child's poisonous blowgun. Less than five minutes after being stuck with a child of blowgun on any part of the body, the Dutch soldiers who initially had a seizure would be killed. In fact, it could be that in seconds they are lifeless. Meanwhile, if the Dayak soldiers get shot and not on the important part, live bullets are issued. After being treated a few weeks, they are ready to fight back. Dayak children's struggle against the Dutch colonial invaders was no less heroic with the fighters who purportedly use bamboo spears to Indonesia. Blowgun becomes one of the unique weapons that can be part of history unforgettable. So now, the skill of becoming a popular sport in the region of Borneo.

The blowgun is a weapon used for hunting as well as in open combat or as a secret weapon for silent killings in combat. The use of blowgun is done by blowing. In terms of use, blowgun has its own advantages because it can be used as a weapon remotely and does not damage the nature because of the natural making material. And one of the advantages of blowgun is to have a maximum shooting accuracy can reach 200 meters (depending on the ability of the man who uses the blowgun). In colonial times in Borneo in ancient times, Dutch troops armed with rifles with the latest technology of its time, while Dayak soldiers generally only rely on blowgun. However, the Dutch sedadu was much more afraid of children affected blowgun than the Dayak soldiers hit by bullets. What makes the colonists tremble is a child of poisonous blowgun. Before leaving for the battlefield, the Dayak soldiers smeared the children's eyes with blowgun with sap of ipuh trees or iren trees. In silence, they act to release a child of blowgun called damek (damak).

\section{B. Making Blowgun}

In the process of making blowgun done in two ways, namely the first skill of the hand of the maker. The second way, namely by using power from nature by utilizing the strength of the flow of cascade water made into a kind of rice pounder mill. Blowgun should not be used to kill others outside the battle. Blowgun can only be used for everyday purposes, such as hunting. Blowgun abstinence is trampled let alone cut with a machete because if it is done means violating customary law, which can lead to the perpetrators will be prosecuted under the customary law.

Blowgun consists of three parts. The first part is the blowgun. Blowgun sticks made of wood-shaped long sphere 
with a hole in it with a wood diameter of about $3-3.5 \mathrm{~cm}$ and a diameter hole 1-1.2 cm. For blowgun, wood used from selected species such as Bunyau wood, Penyau ', Kebaca and Tapang. The size of the blow stem is usually adjusted to the owner of the blowpipe itself, which is about one fifty-five feet long. The other part is, Spear Spear made of steel, the length is $20-30 \mathrm{~cm}$. While the next part is Iron for target spearhead (ribbon header). The ribbon tape is made of iron and tied to the opposite side with the spear eye and at its tip pokes parallel to the stem of the blowgun. Function as a benchmark of the target focus point to be addressed.

In ancient times, every adult male must have blowgun and must be good at puffing. In other words, blowgun is mandatory for Dayak men. Blowgun is the main weapon of Dayak men to hunt and even to fight. Now, blowgun has become a rare item. This is because Dayaks now no longer rely on hunting. The war between the tribes that once happened was now no longer exists. The blowgun craftsmen only make blowgun if there is an order for souvenirs. The shape and workings of blowgun weapons are exactly the same as blowtube weapons in online games. The weapon is a long pipe about 2 meters made of hardwood like ulin, tapang, plepek, or wooden resak. Blowgun is made of wood. The wood is perforated as a place to enter the child blowgun called damak. At the end of the blowgun mounted a spear or machete made of iron or mountain rocks.

\section{Blowgun}

Traditional blowgun consists of bamboo or wooden tubes 1-3m long Blowgun equipped with blowgun with a round shape approximately less than $1 \mathrm{~cm}$ in diameter. Children blowgun (damak) can be made of bamboo in which one end is shaped like a cone made of wood with light mass (from pelawi wood). This works so that the blowgun can streak straight or as a counterweight when separated from the reed. While the other end pointed and usually given a very deadly poison game. The poison is made from the sap of forest vegetation and until now there is still no antidote. Blowgun is used by blowing. The strongness of the breath of the chopper determines the extent to which the blowgun can dart on their targets.

\section{Blowgun and Damak}

The base of the blowgun is usually larger and this is where the blowgun is inserted and blown. Between the reeds, Blowgun and blowgun have a high dependence (mutual support). Although good buluh but blowgun are made carelessly then the result is also less satisfactory and vice versa. This means the two are important to each other in the precision of the target/prey although also the breath of the piercing and the skills are also very important here.

1. Blowgun Stick

Blowgun stick is shaped like pipes. Made of hard round wood, like ulin, lanan, and others. The length of the common blowgun sticks is about 2 meters. But for professional users, the length of the Blowgun stem is made as high as the user's body. This is believed to make users strong breath and shooting right on target. Trunk diameter Blowgun between 2-3 cm. In the center is given a hole with a diameter of about $1 \mathrm{~cm}$. It is in this hole that the blowgun that is the bullets are placed.

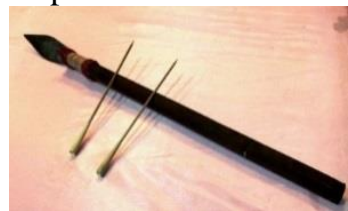

Fig. 1 Blowgun Stick

\section{Damak}

Damak is a single pointed sharp needle. The needle is plugged into a cork-like cushion with bird feathers to allow the blowgun to float constantly toward the target. At the tip of the needle is given a variety of very deadly poison, which is made from various tree sap, plant herbs, and animal poison like snakes, scorpions, and green toads. If blown by an expert, the blowgun can reach more than 100 meters in a constant straight direction. In order to achieve the right target and strong breathing, the length of the blowgun should match the height of the person using them. The most important part of the blowpipe, other than the stem of the blowgun, is the bullet or the blowgun called the damek. The tip of the kid is a pointed blowgun, while the base of the back there is a kind of cork and a kind of tree limb so damak float while heading to the target. The venom of damek by Dayak ethnic Lundayeh called parir. This deadly poison is a mixture of various tree sap, plant herbs and can be animals like snakes. There are various forms of the blowgun, one of them is Langan Adang (Flying Bullet) the blowgun of this one is used to pitch the hunts of distant or high distance, the shape is also unique with the leaves at the back of the child's blowgun, far can reach between 50 and 70 meters.

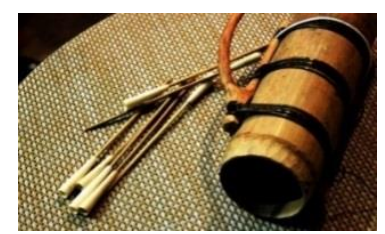

Fig. 2 Damak

\section{Telep}

Since the blowgun are very toxic, then to bring them need a special container called Telep. Telep usually made from bamboo stem segment. A telep can hold between 50-100 pieces of blowgun.

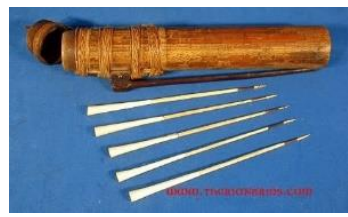

Fig. 3 Telep 


\section{Eyes Spear (Sangkoh) Blowgun}

At the end of the Blowgun Bar, there is a spear called Sangkoh. Boxes Made of hard iron or mountain rocks. Its function is like a bayonet on a rifle, ie as a backup weapon if it runs out of bullets, or for close combat.

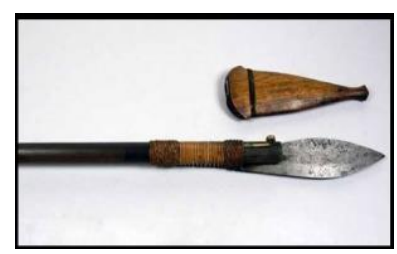

Fig.4 Sangkoh

\section{Blowgun as a Sport Equipment}

Currently, the function of blowgun not only for hunting or for battle but competed in regional sports. Being a sports number is taken into account at every game held in the area. Sports blowgun is not much different from other sports such as sporting shooting or sporting arrows. Usually for the target made a circle of cardboard or paper. The contestants compete to pursue the circle that has been made with the distance determined by the race committee.

"Blowgun used as a tool for hunting and fighting, as the times of blowgun are used as a means to attract tourists domestic and abroad, through a competition," Currently need to foster the seeds of the young generation by providing coaching and assist them by providing facilities and infrastructure. "Blowgun have groups of groups and communities, from this community can be fostered in its development, its facilities and infrastructure, through the exhibition of such a race and create the players of blowgun that are reliable, attractive, tourists," Traditional weapon blowgun typical Dayak tribe used by Dayak tribes since time immemorial, both in hunting and fighting. It is because of this weapon that Dayak tribes are dubbed "Ghost Forces" by the Dutch army, for their greatness disables the opponent unnoticed by the enemy.

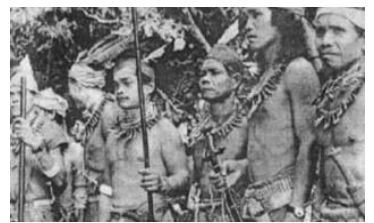

Fig. 4 Dayak Tribes

The Dayak tribe of Kalimantan is not the only one who uses blowgun as a weapon, the native tribes of South America and the Japanese Samurai are also said to have used it.

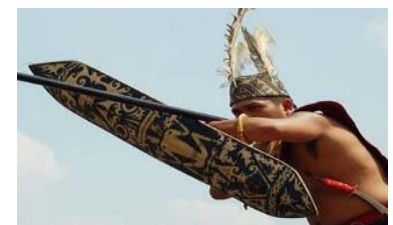

Fig. 5 Dayaknese Using Blowgun
Dayak tribe not only use blowgun as a weapon. Among others, they use mandau (sword / machet), lonjo (spear), and telawang (shield).

\section{RESEARCH METHOD}

This research uses descriptive method with qualitative research form. The population in the study of all Dayak sub-tribes in West Kalimantan which amounted to 21. The sample in this research as many as 21 people customs and Dayak community leaders. The number of 21 people is taken from $10 \%$ of all Dayak sub-tribes in West Kalimantan. In this study used direct communication techniques, with interview guides. Direct observation techniques with observation guides as data collecting tools and Documentation Techniques with data collection tools in the form of recordings, videos, photos of spill activity, in the form of Dayak gear and other official events which become the activity of the piling.

\section{IV.RESUlT AND DISCUSSION}

A. Result

a. Dayak sub-tribes recorded in West Kalimantan

Province:

1. Ahe

2. Air Durian

3. Air Upas

4. Angan

5. Babak

6. Badat

7. Bakati'

8. Bakati' Rara

9. Bakati' Riok

10. Bakati' Sara

11. Banjur

12. Banyadu (terdapat juga di Formosa, Taiwan)

13. Barai

14. Batang LuparProvinsi

15. Batu Entawa

16. Batu Payung

17. Batu Tajam (Dayak Pesaguan Kiri)

18. Baya

19. Benatuq

20. Beginci

21. Bekidoh

22. Belaban

23. Benawas

24. Beriam

25. Bihak

26. Bohokam

27. Bubung

28. Bundu

29. Bugau

30. Bukitan (terdapat juga di Sarawak Malaysia)

31. Butok

32. Cohie

33. Dalam 


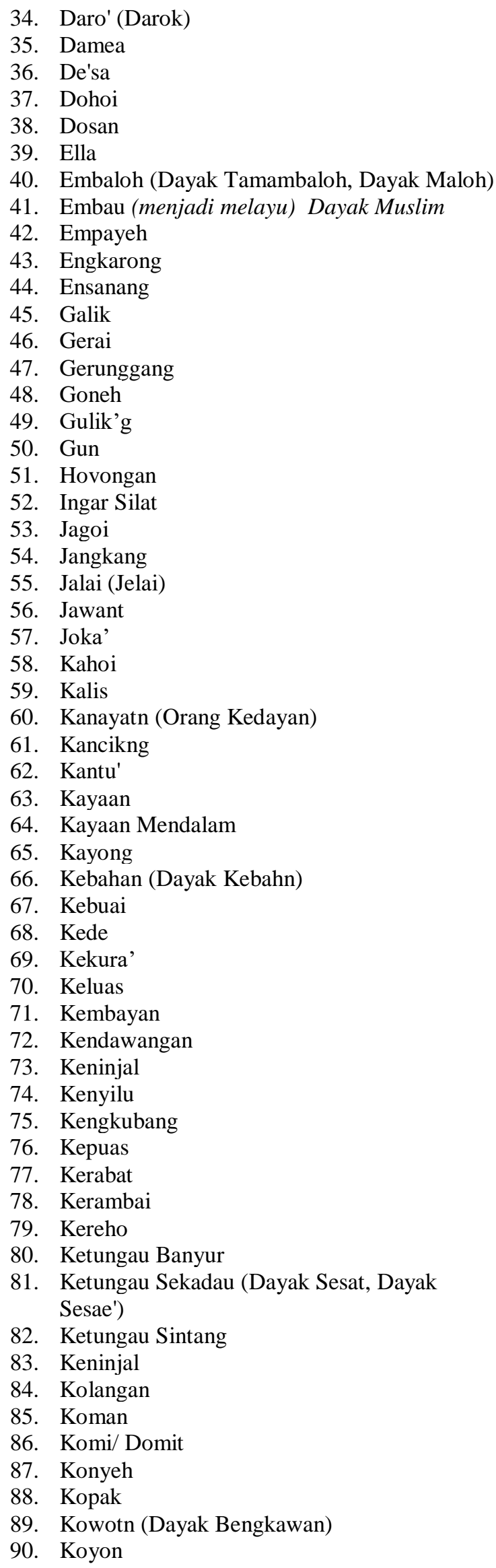

91. Krio

92. Kualant Semanangk

93. Kualantn

94. Kubitn

95. Lamantawa

96. Laur

97. Lara

98. Laya

99. Lebang Nado

100. Lebang Hilir

101. Lebang Hulu

102. Liboy

103. Limbai

104. Linoh (Linuh)

105. Lintang

106. Mayau (Mayao, Majau)

107. Melahoi (Malahui, Malahoi)

108. Mahap

109. Mali

110. Marau (Merau)

111. Membuluq (Membulu)

112. Menggaling

113. Mentebah

114. Menyaya

115. Menyangka

116. Menyuke

117. Mualang

118. Muara

119. Mudu'

120. Muluk

121. Mugut (terdapat juga di Serawak)

122. Nanga

123. Ngabang

124. Ngalampan

125. Ngamukit

126. Nganayat

127. Nyadu (Nyadupm)

128. Orung Daan

129. Ot (Ote)

130. Ot Siau

131. Ot Penyaung (Ot Panyawung)

132. Pandu

133. Pangin

134. Pangkodatn

135. Panu

136. Papak

137. Parangkunyit

138. Pawan

139. Pawatn

140. Payak

141. Pebantan (Dayak Pangkalan Suka)

142. Pelanjau

143. Pengkedang

144. Penyarangan

145. Perigiq

146. Pesaguan

147. Pompakng

148. Pos 
149. Punan

150. Punan Hovongan

151. Punan Uheng Kereho (Ot Nyawong, Dayak Seputan)

152. Punti (Dayak Pontent), terdapat juga di Sabah Malaysia

153. Randu (Randuk)

154. Ransa

155. Riam

156. Ribun (Hibun)

157. Sajan

158. Sami

159. Sane (Sani)

160. Sanggau

161. Sango

162. Sapatoi (Dayak Bung Pah Tung)

163. Saribas

164. Sebaru' (Sebaruk)

165. Sebaung

166. Seberuang

167. Sekajang

168. Sekakai

169. Sekapat

170. Sekayam

171. Sekubang

172. Sekujam

173. Selayang

174. Selako

175. Selawe

176. Selimpat

177. Semandang-Samanakng

178. Semitau

179. Sempadian

180. Senangkan (Senangkat'n)

181. Senganan

182. Senunang

183. Sikukng (Sungkung)

184. Silath Muntok

185. Simpakng

186. Sisakng

187. Sontas (terdapat juga di Serawak)

188. Suhaid (Suaid)

189. Sum

190. Sumanjawat

191. Suru (Suruk, Suruh)

192. Suti

193. Tabuas

194. Tabun

195. Tadietn (Tadatn, Tadan)

196. Taman

197. Tameng (Tamong)

198. Tanjung

199. Tawaeq (Tawang)

200. Tayap Hulu

201. Tebang, sungai Kualatn

202. Tebidah

203. Tengon (Bi Hngon, Dayak Bidayuh Kumba)

204. Tingui

\author{
205. Tinying \\ 206. Toba (Toba', Dayak Tebang di sungai Tayan \\ dan Dayak Cempede') \\ 207. Tola' \\ 208. Undau \\ 209. Uud Danum \\ 210. Uud Sio (terasing dan primitif) \\ 211. Uud Bukhot (terasing dan primitif)
}

\section{b. Blowgun as Souvenir}

Blowgun can be developed or made as a souvenir for tourism purposes. In this way, blowgun is not only sustainable but also can be a source of economic and socialization of society Blowgun can be considered as teaching materials for local wisdom education, in the form of local content subjects (mulok) in school. In this way is expected to raise awareness in the young generation of students (learners) more understanding, loving and ready to preserve blowgun as one of the traditional weapons Dayak high-protected. Blowgun can serve as one of the competing sports branches, in Sports Week with notes for sporting purposes or race damak should not be given poison that can kill.

\section{B. Discussion}

Blowgun is reeds from round logs along the 1.9 meters to 2.1 meters. Blowgun must be made of hardwoods such as ironwood, tapang, lanan, berangbungkan, rasak, or wood plepek and belian tangled. The diameter of two to three centimeters of blowgun with a hole in the middle, with a hole diameter of about one centimeter. Hole blowgun to insert blowgun child. The length of the blowgun should be in accordance with the height of the person who uses them and has been trained. The making of blowgun is done very carefully and carefully by Dayak people. How to manufacture blowgun, hardwood such as ulin that is still shaped beam measuring 10 x 10 centimeters with a predetermined length is hung vertically somewhere. Then the bottom of the block was drilled upward so that the rest of the drilling fell directly to the ground.

The base of the blowgun is usually larger than the muzzle blowgun. At the end of the muzzle mounted spear eyes made of iron or mountain rock called muckloom. The usefulness of this machete for weapons reserves when the hunted and dead prehistoric animals turned to attack the blowgun that has not had time to replenish the blowgun. Mails are tied tightly to the end of the blowgun using a rattan rope. In addition to a machete that is about $15 \mathrm{~cm}$ long, at the end of the blowgun contained iron measuring about two centimeters that are used as a tool aiming. Both devices are placed opposite each other at the end of the muzzle of blowgun. The most important part of the blowpipe, other than the stem of the blowgun, is the bullet or the blowgun. Children blowgun also called damak. The tip of the child is a pointed blowgun, while the base of the back there is a kind of cork of a tree limb so the child blowgun float while heading to the target. For the purposes of the race, damak not given poison like a child of blowgun to hunt. Blowgun 
for battle or hunting are given keratin-keratan along three (3) centimeters at the end of the blowgun with the intention of the end is broken and left in the body of the game until the poison work faster. To put the child blowgun are available special containers called renjung. Made from one bamboo segment carved and tied with rattan and covered, a renjung can store about 50-100 children of blowgun. Damak venom/blowgun is a very lethal poison is a mixture of sharing tree sap, plant herbs and can be animals like snakes and scorpions.

Tree sap used for toxins include sap of ipuh wood, siren wood, or upas, mixed with sap of wi wood, or sap toba. Can animals, like snakes, will strengthen the effects of this poison. Until now there is no antidote to poison blowgun children who have entered the blood vessels. "In the environment of the Dayak community has not been known to poison chop poachers," he said. Effective distance can reach tens of meters, depending on the ability of the blowgun. In addition, this weapon also does not cause sounds. This silent element is very important when targeting enemies and game animals who are careless. There are certain techniques and training required for someone to be proficient and smart to hunt using blowgun. How to take the breath and body position should also be considered because not org careless who can use blowgun well.

The usual position of blowgun with standing or squatting. How to regulate breathing should also be considered so that the target can be hit properly. How to hold the right blowgun, hands should face upwards. The two palms should be close or touch. In addition to the usefulness of hunting and battle, other uses of blowgun are for traditional ceremonies or as dowries in Dayak customary weddings. "When engaged, this blowgun weapon can also be used as a tool for custom wedding party. Blowgun has become rare because the Dayaks now no longer rely on hunting. The inter-ethnic wars that once happened were no longer the case. The blowgun craftsmen only make blowgun if there is an order for souvenirs. The shape and workings of blowgun weapons are exactly the same as blowtube weapons in online games. The weapon is a long pipe about 2 meters made of hardwood like ulin, look, plepek, or wooden resak. Blowgun is made of wood. The wood is perforated as a place to enter the child blowgun called damek. At the tip of the front of the sipet mounted a spear or machete made of mountain rock. Difficult, Making Traditional Blowgun Kompas.com - 02/06/2011.

\section{CONCLUSION}

a. Distribution of blowgun as one of the souvenirs for the purposes of tourism both domestic and foreign countries can be done by socializing blowgun to the community, especially through the younger generation so that they feel owned and ready to take a presence in daily dies.

b. Making blowgun as teaching materials of local wisdom, in local content (mulok) can be done by way of coordinate with Local Government through Head of
District Education Office of Regency / City as education authority in region.

c. Make the activity as one of the branches of sports that competed in School Sports Week, Sports Week (PORDA) or National Sports Week (PON) as a multicultural multi-cultural enhancer can be done in coordination with the Regional Government, the field of Youth and Sports Education along with the Head of the local Education and Culture Office to get the legality of race events.

\section{REFERENCES}

Administrative sub-divisions in Dutch Borneo, ca (1879) (Belanda) Staatsblad van Nederlandisch Indië, s.n., 1849

Ansar, Rahman. (2000) Perspektif Berdirinya Kota Pontianak. Pontianak: Tanpa Penerbit.

Bakker H,P.A. (2014) Sejarah Sanggau. Het.Rijk. Diterjemahkan Pastor Yeremias OFM.Cap. Diterbitkan oleh Dinas Kebudayaan dan Pariwisata. Pemerintah Kabupaten Sanggau.

Brenda, Dorn Conard. (1988) Cooperative Learning and Prejudice Reduction. USA: Social Studies Journal. Aplir/May.

Danang palingindonesia.comhttp://blogsauted.blogspot.co.id /2012/12/ sumpit-dayak-senjata-berburusekaligus.html\#ixzz5Eii72VOw.

Dinas Kebudayan dan Pariwisata Provinsi Kalimantan Barat - Sejarah Kerajaan Tayan Kutipan dari buku sejarah Adat dan Istiadat di Kalimantan Barat, J.U.Lontan

Hasanuddin (2013) Pontianak Masa Kolonial. Penerbit Ombak Yogyakarta

Helius Sjamsuddin (2014) Perubahan di Kalimantan Barat Kerajaan Sintang 1822-1942

http://blogsauted.blogspot.co.id/2012/12/sumpit-dayaksenjata-berburu-sekaligus. html\#ixzz5Eii72VOw

Lontaan, J.U. (1975) Sejarah, Hukum Adat, dan Adat Istiadat Kalimantan-Barat. Pontianak: Peenerbit Pilindo.

Jarolimek, John. (1967) Social Studies in Elementary Education. 5th. edition. NY: McMillan Co. Inc.

Kompas.com"Sumpit Dayak Lebih Ditakuti daripada Peluru", https:// regional. kompas.com/read/2011/06/02/14431016/ Sumpit. Dayak. Lebih. Ditakuti. Dari. Peluru.

Kompas.com"Sulit-Pembuatan-SumpitTradisional",https://internasional.kompas kompas.com/read/2011/06/02/18400750/Sulit.Pembuat an.Sumpit.Tradisional.

Krugg, M.M (1982) History, and the social sciences: New approach to the teaching of social science. Waltham, Massachusetts: Blaisdell Publishing

Mathew B. Milles and A. Michael Huberman. (1992). Analisis Data Kualitatif (terjemahan). Jakarta: Universitas Indonesia Press.

Muhammad Natsir, Sejarah Kalimangtan Barat Pontianak: Tanpa Penerbit. 
Shaver, J.P. (1991) Handbook of Research on Social Studies Teaching and Learning. NY: McMillan Publishing Co.

Undang-Undang Sistem Pendidikan Nasional No.20 Tahun 2003; Balitbang Depdiknas Jakarta

Truhart P., Regents of Nations. Systematic Chronology of States and Their Political Representatives in Past and Present. A Biographical Reference Book, Part 3: Asia \& Pacific Oceania, München 2003, s. 1245-1257, ISBN 3-598-21545-2.

Veth, P.J. (1854) Borneo's Wester Afdeling. Zaltbommel: Noman en Zoon.

Weiner, B. (1979) Theory of Motivation for Some Classroom Experiences, Journal of Abnormal Psychology, 71, 1-12
Weiner, B. (1986) Attribution Theory and Attribution Therapy: Some Theoretical Observation and Suggestions. British Journal of Clinical Psychology, 27, 93-104.

Weiner,B.(1990) History of Motivational Research in Education, Journal of Personality and Social Psychology, 55, 738-748

Yacobus.S.E. Frans..L.BA (2014) Pangsuma Sejarah Perang Majang Desa. Cetakan ke II. Penerbit Dinas Kebudayaan dan Pariwisata Kabupaten Sanggau. Pemerintah Kabupaten Sanggau

Yus Suhardi dkk. Sanggau dari Masa ke Masa Cetakan ke II Penerbit Dinas Kebudayaan dan Pariwisata Kabupaten Sanggau. Pemerintah Kabupaten Sanggau. 